\title{
Human Pneumonia Caused by Bordetella hinzii: First Case in Asia and Literature Review
}

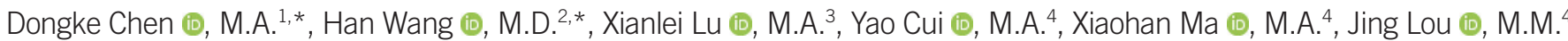 \\ and Haijian Zhou (), M.M. ${ }^{4}$ \\ ${ }^{1}$ Department of Laboratory Medicine, Beijing Hospital, National Center of Gerontology; Institute of Geriatric Medicine, Chinese Academy of Medical Sciences, \\ Beijing, the People's Republic of China; ${ }^{2}$ Department of Clinical Diagnostic Centre, the Fifth Medical Centre, Chinese PLA (People's Liberation Army) General \\ Hospital, Beijing, The People's Republic of China; ${ }^{3}$ Chengdu Fifth People's Hospital, Chengdu, The People's Republic of China; ${ }^{4}$ National Institute for \\ Communicable Disease Control and Prevention, Chinese Center for Disease Control and Prevention and State Key Laboratory for Infectious Disease \\ Prevention and Control, Beijing, The People's Republic of China
}

\section{Dear Editor,}

The genus Bordetella comprises 12 species, some of which cause human diseases. Bordetella hinzii widely exists in poultry and rodents and has occasionally been reported in humans wherein it has been confirmed as a causative agent of pulmonary and digestive infection, and bacteremia, almost invariably in patients with immunodeficiency [1,2]. Only 11 cases of human B. hinzii infection have been reported to date, and none has been found in Asia (Table 1). However, the clinical and epidemiologic characteristics of $B$. hinzii infection remain to be determined. Here, we describe the first Asian case of $B$. hinzii pneumonia to highlight the pathogenicity of this bacterium. As this case was identified during a routine surveillance organized by the Centers for Disease Control and Prevention, the need for ethical approval for the present study was exempted by the Institutional Review Board of Chengdu Fifth People's Hospital, China; verbal consent was obtained from the patient for case presentation.
A 67-year-old woman was admitted to the Neurological Intensive Care Unit in Chengdu Fifth People's Hospital on January 8, 2013 because of fatigue and loss of the abilities to stand, walk, and speak clearly. Computed tomography (CT) showed spontaneous intracerebral hemorrhage involving the ventricles of the brain. The patient had been suffering from type 2 diabetes in the past year but had no other remarkable medical history. After admission, she received symptomatic treatment, supplementary fluids, and antihypertensive treatment. She developed fever on the third day. Her vital signs included a temperature of $38^{\circ} \mathrm{C}$; blood pressure, 148/70 mm Hg; pulse, 84 beats/min; and respiratory rate, 27 breaths/min. Routine blood examination showed a leukocyte count of $9.27 \times 10^{9} / \mathrm{L}$; neutrophil percentage, $88.1 \%$, lymphocyte percentage, $6.5 \%$; platelet count, $91 \times 10^{9} / \mathrm{L}$; and high sensitive C-reactive protein level, $28.9 \mathrm{mg} / \mathrm{L}$. Chest CT examination showed scattered turbidity in both lungs. Therefore, a pulmonary infection was suspected and intravenous cefmetazole ( $1.5 \mathrm{~g}$ daily) was empirically selected and initiated. The patient's
Received: July 3, 2020

Revision received: September 4, 2020

Accepted: January 6, 2021

Corresponding author: Jing Lou, M.M.

National Institute for Communicable Disease Control and Prevention, Chinese Center for Disease Control and Prevention, No. 155 Changbai Road, Beijing 102206, People's Republic of China

Tel: +86-10-58900713, Fax: +86-10-58900700, E-mail: loujing@icdc.cn

Co-corresponding author: Haijian Zhou, M.M.

National Institute for Communicable Disease Control and Prevention, Chinese Center for Disease Control and Prevention, No. 155 Changbai Road, Beijing 102206, People's Republic of China

Tel: +86-10-58900784, Fax: +86-10-58900700, E-mail: zhj_0901@163.com

*These authors contributed equally to this study.

\section{(c) (1) (8)}

\section{(c) Korean Society for Laboratory Medicine}

This is an Open Access article distributed under the terms of the Creative Commons Attribution Non-Commercial License (https://creativecommons.org/licenses/by-nc/4.0) which permits unrestricted non-commercial use, distribution, and reproduction in any medium, provided the original work is properly cited. 





condition improved, and she was discharged on January 15, 2013.

The blood culture result was negative. Direct gram staining and microscopic examination of the sputum revealed gram-negative rods in the neutrophils. After 18 hours incubation at $35^{\circ} \mathrm{C}$, colorless colonies were detected on blood, chocolate, and MacConkey agar plates, which were all gram-negative rods. One isolate from each plate was selected for identification. Initial identification performed using the API 20NE strip (bioMérieux, Lyons, France) classified the isolate as Bordetella avium with a $96.6 \%$ confidence, which could not be used to distinguish species in the genus Bordetella. The selected isolate from the blood agar plate, designated strain A2799, was subject to further identification using matrix-assisted laser desorption/ionization time-of-flight mass spectrometry (MALDI-TOF-MS) (Bruker, Leipzig, Germany) and $16 S$ rRNA gene sequencing. Both methods classified this strain as $B$. hinzii. Antibiotic susceptibility testing was performed using the Kirby-Bauer method. The strain was found to be susceptible to the most commonly used antibiotics, and our patient recovered well through therapy with cefmetazole, which is similar to cefoxitin and ceftazidime, to which the strain was found to be susceptible.

Furthermore, the whole-genome sequence of A2799 (GenBank accession no. SRP081450) was obtained. Phylogenetic trees were constructed using a distance matrix based on the presence or absence of genes (pan-genome tree) and single nucleotide polymorphisms in the core genome (core-genome tree) for A2799 and 27 other Bordetella strains (Fig. 1). In both trees, A2799 clustered with two B. hinzii strains and with B. pseudohinzii, further suggesting that A2799 is B. hinzii. The three "classical" Bordetella species, B. pertussis, B. parapertussis, and $B$. bronchiseptica, were closely associated in both the pangenome and core-genome phylogenetic trees, indicating that these three species were derived from a recent common ancestor (Fig. 1).

Our patient had been suffering from cerebral hemorrhage but had no history of physical injury or trauma on admission. In patients with $B$. hinzii infections, the medical history often reveals a recent exposure to poultry. However, there was a history of avian exposure for this patient. Thus, the exact nature of the exposure in our patient remains unknown.

The identification of $B$. hinzii was inconclusive or inaccurate with a biochemical identification system, consistent with a previous case [1]. 16S rRNA gene sequencing and routine MALDITOF-MS are reliable for identifying $B$. hinzii [1]. Furthermore, whole-genome sequencing is increasingly being applied to identify clinical microorganisms. Therefore, it is likely that some species that could not previously be identified by traditional biochemical methods will increasingly be discovered. B. hinzii infection is rare but potentially fatal. However, antibiotic therapy often re-


Fig. 1. Phylogenetic trees based on whole-genome sequencing and analysis. (A) Phylogenetic tree based on the gene content (pan-genome tree). (B) Phylogenetic tree based on 810 core-genome single nucleotide polymorphisms (core-genome tree). 
sults in a favorable outcome.

\section{AUTHOR CONTRIBUTIONS}

Zhou $\mathrm{H}$ designed the study. Chen $\mathrm{D}$, wang $\mathrm{H}$, Lu X performed the data collection and sampling and carried out the experiments. Cui Y, Ma X, Lou J, Zhou H carried out the sequencing and data analysis. Chen $\mathrm{D}$, Lou $\mathrm{J}$ and Zhou $\mathrm{H}$ wrote the manuscript. All authors read and approved the final version of the manuscript.

\section{CONFLICTS OF INTEREST}

No potential conflicts of interest relevant to this article were reported.

\section{RESEARCH FUNDING}

This work was supported by grants from the Priority Project on Infectious Disease Control and Prevention (grant numbers 2017ZX10303405-002 and 2018ZX10201002-005) from the Ministry of Science and Technology of the People's Republic of China.

\section{ORCID}

$\begin{array}{ll}\text { Dongke Chen } & \text { https://orcid.org/0000-0002-2647-5499 } \\ \text { Han Wang } & \text { https://orcid.org/0000-0003-3102-4235 } \\ \text { Xianlei Lu } & \text { https://orcid.org/0000-0002-8821-8754 } \\ \text { Yao Cui } & \text { https://orcid.org/0000-0001-9406-5419 } \\ \text { Xiaohan Ma } & \text { https://orcid.org/0000-0002-6533-1658 } \\ \text { Jing Lou } & \text { https://orcid.org/0000-0003-1855-8945 }\end{array}$

Haijian Zhou

https://orcid.org/0000-0002-8742-5399

\section{REFERENCES}

1. Fabre A, Dupin C, Bénézit F, Goret J, Piau C, Jouneau S, et al. Opportunistic pulmonary Bordetella hinzii infection after avian exposure. Emerg Infect Dis 2015; 21:2122-6.

2. Vandamme P, Hommez J, Vancanneyt M, Monsieurs M, Hoste B, Cookson $\mathrm{B}$, et al. Bordetella hinzii sp. nov., isolated from poultry and humans. Int J Syst Bacteriol 1995;45:37-45.

3. Funke G, Hess T, von Graevenitz A, Vandamme P. Characteristics of Bordetella hinzii strains isolated from a cystic fibrosis patient over a 3-year period. J Clin Microbiol 1996;34:966-9.

4. Cookson BT, Vandamme P, Carlson LC, Larson AM, Sheffield JV, Kersters $\mathrm{K}$, et al. Bacteremia caused by a novel Bordetella species, "B. hinzii". J Clin Microbiol 1994;32:2569-71.

5. Kattar MM, Chavez JF, Limaye AP, Rassoulian-Barrett SL, Yarfitz SL, Carlson LC, et al. Application of 16S rRNA gene sequencing to identify Bordetella hinzii as the causative agent of fatal septicemia. J Clin Microbiol 2000;38:789-94.

6. Gadea I, Cuenca-Estrella M, Benito N, Blanco A, Fernandez-Guerrero ML, Valero-Guillen PL, et al. Bordetella hinzii, a "new" opportunistic pathogen to think about. J Infect 2000;40:298-9.

7. Arvand M, Feldhues R, Mieth M, Kraus T, Vandamme P. Chronic cholangitis caused by Bordetella hinzii in a liver transplant recipient. J Clin Microbiol 2004;42:2335-7.

8. Fry NK, Duncan J, Edwards MT, Tilley RE, Chitnavis D, Harman R, et al. A UK clinical isolate of Bordetella hinzii from a patient with myelodysplastic syndrome. J Med Microbiol 2007;56:1700-3.

9. Hristov AC, Auwaerter PG, Romagnoli M, Carroll KC. Bordetella hinzil septicemia in association with Epstein-Barr virus viremia and an Epstein-Barr virus-associated diffuse large B-cell lymphoma. Diagn Microbiol Infect Dis 2008;61:484-6.

10. Palacián Ruiz MP, Vasquez Martinez MA, Lopez Calleja Al. Respiratory infection caused by Bordetella hinzii. Arch Bronconeumol 2013;49:40910. 